\title{
Instituições Fortes, Moeda Estável e Banco Central do Brasil Autônomo
}

\author{
Eduardo de Vasconcelos Raposo \\ Yuri Kasahara ${ }^{\text {II }}$
}

IProfessor e pesquisador do Departamento de Sociologia e Política da Pontifícia Universidade Católica do Rio de Janeiro (PUC-Rio). E-mail: raposo@puc-rio.br

IIDoutor em Ciência Política pelo Instituto Universitário de Pesquisas do Rio de Janeiro (IUPERJ) e pesquisador associado do Centre for Development and the Environment, da

Universidade de Oslo. E-mail: yuri.kasahara@sum.uio.no

O Brasil precisava ter uma moeda estável. E para ter uma moeda estável precisava ter pelo menos um início de Banco Central (Otávio Gouveia de Bulhões, idealizador da Sumoc e do Banco Central do Brasil)

Bancos centrais modernos devem afirmar sua independência em relação aos mercados financeiros tão vigorosamente quanto afirmam sua independência em relação à política (Alan S. Blinder, vice-chairman Federal

Reserve Board - 1994/1996)

\section{INTRODUÇÃO}

A concessão de autonomia aos bancos centrais em todo o mundo ca-
pitalista se transformou, sobretudo a partir da década de 1990,
as coma de acalorados debates que passaram a mobilizar, não apenas
círculos acadêtes de policy-makers.
O pressups também parte significativa dos
em relação a seus governos discussão é que que bancos centrais independentes
ter baixos índices de inflação, uma veficientes na tarefa de man-
pria natureza política, temem, sobretudo nos períodos eleitorais, ado-
tar medidas impopulares, como, por exemplo, aumentar as taxas de ju-

DADOS - Revista de Ciências Sociais, Rio de Janeiro, vol. 53, n4 4, 2010, pp. 921 a 958. 
ros que afetarão o crescimento econômico elevando o nível de desemprego.

Apesar desse recente interesse acadêmico e da presença recorrente do tema no debate público nacional, a discussão sobre a independência do banco central não é uma novidade na trajetória da política econômica brasileira. Desde a criação da Superintendência da Moeda e do Crédito (Sumoc) em 1945 até o atual período de estabilidade econômica iniciado em meados da década de 1990, o grau de autonomia concedido à autoridade monetária mostra-se como um tema controverso. Ao analisarmos o percurso institucional da autoridade monetária no Brasil, podemos perceber que o grau de sua autonomia tem variado de acordo com as preferências e prioridades de governos em relação à estratégia de desenvolvimento econômico a ser implementada.

Com essa perspectiva, o presente artigo destina-se a discutir a autonomia do Banco Central do Brasil (BCB) e sua tortuosa relação com a estabilidade da moeda nacional. Para tanto, fixamos-nos em uma argumentação que se apoia em duas hipóteses centrais, desenvolvidas ao longo do texto.

1) De acordo com a primeira hipótese, a estabilidade da moeda nacional depende, para além do equilíbrio das contas públicas e da autonomia do Banco Central, da estabilidade política e institucional do próprio Banco Central. Para fins desse artigo, utilizamos para medir tal estabilidade, não só o grau de circulação dos presidentes do Banco Central, como também dos ministros da Fazenda ${ }^{1}$. Um segundo indicador importante que será utilizado é o da composição do Conselho Monetário Nacional (CMN), uma vez que no arranjo institucional brasileiro esse órgão detém a prerrogativa de elaboração da política monetária. Segundo nossa hipótese, a estabilidade política e institucional da autoridade monetária é maior em situações de baixa circulação de titulares da área econômica e de composição mais reduzida do $\mathrm{CMN}$, uma vez que torna esta instituição mais impermeável a demandas clientelísticas (Raposo, 1997).

2) Uma segunda hipótese nos remete à autonomia concedida por diferentes governos à Sumoc e ao BCB na execução das políticas monetárias e creditícias do país. A trajetória brasileira mostra que, em períodos históricos desenvolvimentistas, os governos, que priorizaram implementar altas taxas de crescimento à economia nacional, tenderam a submeter a autoridade monetária ao Poder Execu- 
tivo. Por outro lado, em períodos estabilizadores, com governos preocupados em controlar desequilíbrios fiscais e altas taxas de inflação, os mesmos tenderam a atribuir maior autonomia à autoridade monetária. Assim, a autonomia dessas instituições dependeu das preferências que diferentes governos ou coalizões políticas majoritárias apresentaram, ao longo do tempo, em relação às suas estratégias de política econômica (Raposo, 1997).

A fim de testar e refletir sobre as hipóteses acima enumeradas, realizamos uma análise comparativa da atuação da autoridade monetária brasileira dos governos compreendidos entre 1945 (Dutra) e 2003, final do segundo mandato de Fernando Henrique Cardoso. Com essa perspectiva, procuramos integrar o processo de institucionalização da autoridade monetária brasileira na trajetória mais ampla do desenvolvimento político e econômico nacional, ressaltando os conflitos e contradições nele presentes (Raposo, 1997; Thelen, 1999). Portanto, em uma perspectiva mais geral, este trabalho considera as condições políticas e as motivações econômicas como elementos indispensáveis para avaliarmos os momentos de maior ou menor autonomia de bancos centrais ao longo do tempo (Raposo, 1997; Quaglia, 2005; Corazza, 2006; Patrício, 2001; Santos e Patrício, 2002; Sola, Garman e Marques, 2002).

Sobre a metodologia adotada, esse artigo se vale de dois procedimentos. Um deles é a utilização de entrevistas realizadas com alguns dos principais presidentes do Banco Central do Brasil que, dialogando com cenários por vezes extremamente adversos, explicam estratégias, defendem projetos, interpretam fatos e expõem-se como protagonistas de nossa história política e econômica moderna. Uma história engendrada por uma lógica que envolve a ação dos atores políticos que, a um só tempo, influenciaram e foram condicionados por conjunturas de crises, conflitos e pelo caráter de nossas instituições públicas. A contribuição dos depoimentos está intimamente ligada ao reconhecimento das visões e versões dos fatos narrados como manifestações de determinados momentos históricos da construção institucional da Sumoce e do Banco Central do Brasil. Essas versões subjetivas e comprometidas com posições políticas e institucionais são mais do que simples visões ideológicas e parciais. Constituem-se, na verdade, em elementos a partir dos quais será possível conhecer e esclarecer fatos e processos históricos aparentemente contraditórios. Assim, essas entrevistas oferecem um material de grande valor para o pesquisador e que, juntamente 
com outros documentos, possibilitam um entendimento mais rico e consistente da formação institucional brasileira.

Um segundo procedimento é a análise comparativa dos indicadores de estabilidade institucional, da autonomia da autoridade monetária e do comportamento da taxa de inflação em relação às políticas econômicas adotadas por cada governo em questão (desenvolvimentistas ou estabilizadoras). Com essa comparação, procuramos estabelecer correlações que permitam melhor compreender os contextos nos quais as autoridades monetárias desfrutaram de maior ou menor autonomia.

$\mathrm{O}$ artigo desenvolve-se em três partes. Na primeira, resumimos os principais achados da bibliografia mais significativa sobre a autonomia dos bancos centrais. Na segunda parte, apresentamos a trajetória do caso brasileiro, desde a criação da Sumoc até o período recente de autonomia do Banco Central do Brasil (Bacen) no governo Fernando Henrique Cardoso. A terceira parte procura sintetizar a argumentação desenvolvida em um quadro comparativo dos diferentes governos analisados. Por fim, concluímos propondo algumas questões a serem desenvolvidas nas próximas pesquisas sobre a institucionalização da autoridade monetária no Brasil.

\section{O DEBATE RECENTE SOBRE AUTONOMIA DE BANCOS CENTRAIS}

Nas últimas décadas, alguns trabalhos dedicaram-se a discutir não só a possível relação existente entre autonomia dos bancos centrais e estabilidade monetária, mas também as circunstâncias e as motivações que levaram à sua adoção por parte dos bancos centrais, reanimando o debate sobre sua eficiência, seus limites e suas características. Nesse contexto, a literatura sobre o tema consolidou-se em torno de duas perguntas: 1) por que bancos centrais autônomos são benéficos para a economia de um país? e 2) o que levaria governos a adotarem bancos centrais autonômos, a despeito dos incentivos em contrário?

Um dos trabalhos que tenta responder à primeira questão foi formulado por Alan Blinder, para quem autonomia significa que os bancos centrais devem dispor de liberdade para decidir como tentar atingir seus objetivos; porém, isto não quer dizer que o banco, por si só, pode selecionar tais objetivos. Blinder acredita que em regimes democráticos as autoridades políticas devem indicar os objetivos a serem atingidos pelos seus bancos centrais. 
As razões técnicas para a adoção desta autonomia encontram-se bem resumidas na sua argumentação, em que

a política monetária, por sua própria natureza, requer um horizonte de longo prazo [...], mas políticos em países democráticos - e até mesmo não democráticos - não são conhecidos nem por sua paciência, nem por sua visão aguda de longo prazo. [...] Sabendo disso, muitos governos sabiamente tentam despolitizar a política monetária, por exemplo, colocando-a nas mãos de tecnocratas não eleitos com longa experiência no governo e protegidos do agito da política. O raciocínio é o mesmo de Ulisses: ele sabia que iria ter melhores resultados a longo prazo se se amarrasse ao mastro, apesar de saber que não se sentiria muito bem com isto a curto prazo! (Blinder, 1999:76) ${ }^{2}$

Blinder nos fala, também, da independência do banco central em relação aos mercados financeiros.

Se o banco central se esforçar demais para agradar aos mercados, é provável que tacitamente adote os horizontes extremamente curtos dos mercados como seus próprios. Isso pode criar um perigoso fenômeno do tipo "cachorro perseguindo o próprio rabo", em que o mercado reage, ou melhor, reage exageradamente, a percepções sobre o que o banco central poderia fazer e o banco central recorre aos mercados para orientação sobre o que deveria fazer. (Blinder, 1999:79)

Outro autor é o cientista político Arend Lijphart que chama a atenção para a política monetária, que se tornou particularmente importante no mundo contemporâneo a partir do ano de 1971,

quando o presidente dos Estados Unidos, Richard Nixon, desvalorizou o dólar americano rompendo a relação fixa do dólar com o ouro e com as outras moedas, estabelecida no acordo de Bretton Woods, em 1944. Nessa situação muito mais incerta de flutuação das taxas de câmbio, a independência dos bancos centrais se transformou num instrumento ainda mais importante na limitação da instabilidade de preços. (Lijphart, 2003:267)

Sylvia Maxfield (1997), por sua vez, tenta entender as razões que levaram inúmeros governos a conceder independência a suas autoridades monetárias a partir da década de 1990. Ela nos lembra que o aumento da independência dos bancos centrais, verificado na Europa, encontra-se, em parte, ligado ao Tratado de Maastricht, de 1992, por ter esta- 
belecido a independência dos bancos centrais como condição necessária para a participação na nova moeda europeia.

Maxfield também chama a atenção para o caso específico da América Latina - povoada por Estados nacionais com dificuldades de se financiarem de maneira não inflacionária -, onde os bancos centrais passaram a ser olhados como instituições estratégicas, recebendo pressões vindas de mercados financeiros muito mais liberalizados e credores de importantes dívidas de vários de seus países, para se tornarem independentes. No continente latino-americano, a independência dos bancos centrais ocorreu, sobretudo, a partir dos anos de 1990, em um ambiente no qual não havia mais recursos financeiros abundantes, como ocorria nos anos de 1970. Ao contrário, havia desconfiança por parte do mercado e das instituições financeiras em relação aos países que vinham demostrando dificuldades em pagar suas dívidas.

Outro caso seria a adoção, por países recém-saídos do comunismo, de bancos centrais independentes, situação que se encontra ligada às preferências dos mercados financeiros dos quais estes Estados, agora novos membros do mundo capitalista, precisavam se aproximar.

Nesse ambiente - em que os bancos centrais passaram a protagonizar parte importante da discussão sobre o modelo institucional a ser adotado pelas sociedades contemporâneas - é que surge o interesse em se verificar se bancos centrais autônomos são realmente mais adequados para controlar o processo inflacionário.

Como já dito anteriormente, a pressuposição básica é a existência de uma tensão estrutural entre a lógica política e a lógica econômica. Bancos centrais submissos a governos prioritariamente preocupados em promover o crescimento econômico e o aumento dos níveis de emprego a fim de garantir votos ou aprovação popular acabam por alimentar processos inflacionários. Ou seja, governos que pressionam seus bancos centrais para que, através do aumento da liquidez da economia, se vinculem a tais objetivos, produzem, em última instância, o aumento da inflação. Ou, ainda, governos que temem os efeitos políticos negativos de medidas recessivas - como a elevação das taxas de juros, o desaquecimento da economia e o aumento das taxas de desemprego - têm poucos incentivos para controlar processos inflacionários. De modo contrário, países com bancos centrais independentes para perseguir a estabilidade monetária poderiam enfrentar de modo mais eficiente tais processos (Bibow, 2004). 
Tendo este cenário como pano de fundo, surgiram inúmeros trabalhos que examinaram aspectos dos bancos centrais que poderiam colaborar para o aumento de suas autonomias e, supostamente, para o aumento da estabilidade monetária de seus países, considerando esta autonomia como resultante de diferentes fatores, tais como os legais, os políticos, os econômicos e, até mesmo, a personalidade de seus dirigentes.

No artigo "Measuring the Independence of Central Banks and its Effect on Policy Outcomes", Cukierman, Webb e Neyapti (1992) realizam um dos mais completos estudos sobre a mensuração de tal correlação construindo três conjuntos de indicadores que foram aplicados a 72 países ( 21 industrializados e 51 em desenvolvimento) observados a cada década, desde 1950 até 1989 . O primeiro conjunto de indicadores é relativo à independência legal dos bancos centrais; o segundo, sobre a rotatividade dos seus presidentes; o terceiro é baseado nas respostas de especialistas a um questionário. Com base nesses índices, os autores demonstraram a existência de uma forte correlação entre bancos centrais independentes e baixas taxas de inflação em países industrializados. Em relação aos países em desenvolvimento, as correlações mostraram-se indeterminadas.

Se para a cientista política Susanne Lohman (1998:443) é verdade que a independência dos bancos centrais só se correlaciona positivamente com estabilidade da moeda nos países desenvolvidos, é verdade, também, que meros estatutos legais ou instituições formalmente independentes, a despeito dessas correlações positivas, não têm a capacidade de reverter processos inflacionários. Para Lohman, um dos elementos que contribuiria de forma decisiva para a autonomia de bancos centrais seria a existência de um sistema de checks and balances capaz de propiciar pontos de veto aos atores políticos relevantes. Segundo a autora, em sistemas federativos, normalmente com mais possibilidades de pontos de veto por diferentes atores políticos, a reversão da independência de um banco central seria mais difícil. Por isso, a autora chama a atenção para a correlação positiva entre sistemas federativos e bancos centrais independentes. Mais uma vez, porém, essa correlação só se mostra convincente quando olhamos para países considerados desenvolvidos, não sendo forte em países em desenvolvimento.

Para melhor entendermos as correlações indeterminadas entre autonomia de bancos centrais e estabilidade monetária em países em desenvolvimento, deve-se considerar que até a década de 1980 esses paí- 
ses não respeitavam, de maneira efetiva, a eventual independência legal de seus bancos centrais porque, frequentemente, a preocupação prioritária de seus governos era a promoção do crescimento econômico e do pleno emprego, e não a busca da estabilidade monetária. Assim, os bancos centrais desses países tenderam a atuar mais como bancos de fomento, fornecendo crédito para o desenvolvimento da economia a despeito da necessidade de controlar seus processos inflacionários, tendência esta que adquire predominância apenas a partir da crise dos anos de 1970.

Sobre o caso brasileiro, Sola, Garman e Marques (2002) mostram que a estabilidade recente de preços precedeu à maior autonomia do Banco Central. No mesmo sentido, Mendonça (1998) afirma não existir uma relação de causalidade estrita entre o aumento gradual do grau de independência do Banco Central do Brasil e a estabilidade de preços, sobretudo no período pós-Plano Real; ao contrário, o aumento da independência foi resultado do sucesso da estabilização derivada deste Plano.

Francisco Rigolon (1993) assinala, igualmente, que a existência de bancos centrais independentes não seria condição suficiente para a manutenção de baixas taxas de inflação, sendo a autonomia recomendável como mecanismo preventivo após processos de estabilização bem-sucedidos, e que os mesmos só se tornam efetivos quando a sociedade chega a um consenso político que afaste a expansão monetária como instrumento de política econômica.

Chama, ainda, a atenção para o fato de a "rotatividade dos presidentes ser um indicador adequado para medir a independência real nos países em desenvolvimento, mas não nos desenvolvidos" e que "a rotatividade indicou progressiva deterioração na independência do Bacen, ao longo das décadas de 1960, 1970 e 1980". Acentua, também, que "inflação, indexação, dívida e déficit públicos afetam negativamente a independência dos bancos centrais", e que "a magnitude do mercado financeiro afeta positivamente [sua] independência [...]" (Rigolon, 1993).

Apesar das contribuições trazidas por esses e outros trabalhos, gostaríamos de ressaltar que pouca atenção foi dada a estudos de caso em que são analisadas as condições políticas e as motivações econômicas que levam países em desenvolvimento, como o Brasil, a concederem maior ou menor autonomia a suas autoridades monetárias. Como 
Taylor (2009) sugere, é necessário entender a construção da autoridade monetária brasileira como um processo gradual e cumulativo. Em sua argumentação, pequenas alterações na forma de elaboração e implementação das políticas monetária e econômica contribuíram decisivamente, ao longo do tempo, para a consolidação da autonomia da autoridade monetária brasileira.

Mais recentemente, após o sucesso do Plano Real e o maior insulamento experimentado pelo Banco Central do Brasil, surgiram trabalhos que analisam os mecanismos de prestação de contas da autoridade monetária perante o Congresso Nacional e que discutem a legitimidade da ação da autoridade monetária independente no contexto das sociedades democráticas (Santos e Patrício, 2002; Patrício, 2001). A partir desses trabalhos, podemos perceber que as prerrogativas de formulação da política monetária, no caso brasileiro, encontram-se historicamente concentradas no Poder Executivo federal. Por incorrer nos custos - e colher os benefícios - resultantes da política monetária e pela ausência de pontos de veto institucionais expressivos, historicamente as preferências do Poder Executivo federal - em particular do presidente da República - têm sido o principal elemento a garantir a estabilidade política da autoridade monetária e, consequentemente, de sua autonomia para atingir os objetivos desejados.

Com essas perspectivas, passamos então a analisar a trajetória de institucionalização da autonomia da autoridade monetária brasileira.

\section{A SUPERINTENDÊNCIA DA MOEDA E DO CRÉDITO - SUMOC E SEU CONSELHO}

No Brasil, a ideia de criação de um banco central independente foi cogitada inúmeras vezes. Passo importante neste sentido foi dado com a criação da Sumoc, ainda no apagar das luzes do Estado Novo, em $1945^{3}$. Por ocasião da criação da Sumoc foi instituído o seu Conselho, que teve como função definir a política monetária e creditícia do país e estabelecer, por conseguinte, os limites de atuação, tanto da própria Sumoc, como do Banco do Brasil.

Se é verdade que a Sumoc e, mais nitidamente, o Banco Central transformaram-se gradativamente em instituições dotadas de princípios técnicos, compostas de funcionários admitidos por concurso que, para perseguirem suas metas, agiram progressivamente com mais autono- 
mia, é verdade também que há variações e ponderações a serem feitas a esse respeito.

Primeiramente, foram diferentes os padrões de insulamento dessas instituições em seus sucessivos períodos históricos. Há, também, significativas alterações nos relacionamentos, tanto da Sumoc quanto do Banco Central, com os conselhos aos quais se ligaram por laços de dependência e através dos quais se relacionaram com o Poder Executivo. Estes conselhos tinham como atribuição estabelecer as metas a serem por elas seguidas e tiveram as composições políticas as mais diversas possíveis. Em alguns períodos, a Sumoc e principalmente o Banco Central foram mais autônomos, relacionando-se com o Poder Executivo através de conselhos de composição mais técnica; em outros, perderam suas autonomias, subordinando-se a conselhos mais políticos, ou através de suas ligações diretas com o Ministério da Fazenda e com o Banco do Brasil, órgãos comandados pelo Poder Executivo.

Como veremos no decorrer da análise, governos que adotaram políticas desenvolvimentistas tenderam a inchar esses Conselhos, que acabaram se transformando em verdadeiras assembleias nas quais tinham assento, inclusive, instituições fiscalizadas pelo próprio Conselho. Governos preocupados em estabilizar a economia, por sua vez, tenderam a reduzir o número de membros do Conselho Monetário como forma de insular a formulação da política monetária de interesses particulares e corporativos.

Assim, a Sumoc, o Banco Central e, sobretudo, seus Conselhos, foram inseridos em diferentes arranjos institucionais produzidos em épocas, governos e contextos internacionais muito singulares, tendo feito parte de um Estado que frequentemente promoveu parcerias políticas preferenciais e corporativas com alguns grupos e classes, ao mesmo tempo em que excluiu e abandonou outros.

O projeto de criação da Sumoc previa que este órgão - subordinado ao Ministério da Fazenda -, além de exercer o controle monetário nacional, prepararia o terreno para a constituição de um banco central autônomo. Sua criação foi, de fato, a primeira tentativa institucional mais clara de se formular e executar uma política monetária de maneira mais autônoma.

Porém, na verdade, a Sumoc atuava à sombra do Banco do Brasil, já que este estava fortemente representado nos Conselhos da Sumoc, como se 
pode ver: Ministério da Fazenda (presidente), presidente do Banco do Brasil (vice-presidente), diretores das Carteiras de Câmbio e Redesconto do Banco do Brasil, diretor da Caixa de Mobilização e Fiscalização Bancária e, finalmente, pelo diretor executivo da Sumoc. Isto limitava, na prática, sua capacidade de resistir às pressões expansionistas sobre o crédito exercidas pelas operações do Banco. O fato de não existir, à época, um processo ordenado de emissão de papel-moeda, e de serem, em geral, muito frágeis os instrumentos de controle das atividades bancárias, prejudicava também a autonomia operacional da Sumoc.

Outras relações que uniram o Banco do Brasil à Sumoc através de seu Conselho também nos ajudam a esclarecer a pouca autonomia de que desfrutou a Superintendência. Primeiramente, é preciso considerar que, na divisão de tarefas entre essas instituições, coube ao Banco do Brasil atuar como órgão executor das decisões do Conselho da Sumoc, como Banco dos bancos, e como depositário das reservas internacionais, continuando, portanto, a atuar sempre como agente financeiro do governo. Para tanto, recebia crédito do Tesouro Nacional, arrecadava tributos ou rendas federais e realizava pagamentos e suprimentos necessários à execução do Orçamento Geral da União.

Um efeito colateral da forte presença de diretores do Banco do Brasil no Conselho da Sumoc foi a frequente diluição de suas atribuições técnicas quando incorporou a seus quadros membros de formação essencialmente política, como Ovídio Xavier de Abreu, Tancredo Neves e José Maria Alkmin, durante as décadas de 1940 e 1950, por terem sido titulares da Carteira de Redesconto quando esta pertencia ao Banco do Brasil.

No interior do próprio Banco do Brasil os conflitos e resistências à criação de um Banco Central realmente autônomo vinham de longa data. Segundo Casimiro Ribeiro, antigo funcionário do Banco do Brasil e que pertenceu ao grupo "sumoqueano" ${ }^{4}$, "essa discussão já existia na década de 1940 e esquentou na década de 1950. As pressões vinham dos funcionários do Banco do Brasil [...] de funcionários que eram senadores da República, funcionários vereadores, deputados, professores $[\ldots]^{\prime \prime}$.

O fato é que um maior controle bancário e creditício exercido por uma instituição estatal mais impermeável aos interesses clientelísticos provocou reações. 
Octávio Gouveia de Bulhões confirma que o projeto da Sumoc, mesmo tendo sido apenas um embrião de Banco Central, não conseguiu ser implantado em sua totalidade, e permaneceram nas mãos do Banco do Brasil algumas de suas atribuições legalmente estabelecidas, como o recolhimento dos depósitos compulsórios.

Apesar de todos os avanços conseguidos, a Sumoc não conseguiu se transformar em um Banco Central independente. A constituição de um sistema de contas das autoridades monetárias permitiu à instituição avançar na distinção das contas públicas, porém não adquiriu controle sobre elas (Malan, 1983).

Mesmo que a Sumoc tenha representado um importante passo na direção de mais racionalidade na execução das políticas monetária e cambial, a mesma não obteve autonomia em suas ações, permanecendo subordinada ao Banco do Brasil, ao Ministério da Fazenda e a conselhos de formação frequentemente política.

\section{O BANCO CENTRAL DO BRASIL E O CONSELHO MONETÁRIO NACIONAL}

Um segundo momento importante no processo de autonomização dos instrumentos de gestão monetária no Brasil se deu por ocasião da reforma bancária realizada pelo governo Castelo Branco, em 1964, quando foram criados o Banco Central do Brasil e o Conselho Monetário Nacional (Lei 4.595/64), tendo ocorrido, nessa ocasião, um nítido fortalecimento dos instrumentos de gestão monetária e financeira que se credenciaram política e juridicamente para exercer um controle bastante mais incisivo, tanto sobre a receita, quanto sobre os gastos públicos nacionais.

O então recém-criado Banco Central, subordinado ao Conselho Monetário Nacional - órgão máximo do novo sistema financeiro -, adquire poderes claramente superiores aos exercidos pela agora extinta Sumoc, diminuindo, consequentemente, as atribuições do Banco do Brasil, o que não deixou de provocar resistências ${ }^{6}$. Octávio Gouvêa de Bulhões, ministro da Fazenda do governo Castelo Branco e patrocinador da proposta de criação do Banco Central, apesar de seu espírito extremamente avesso a polêmicas, e com tendências a amenizar a gravidade dos conflitos que envolveram a criação do Banco Central, admite as reações advindas da burocracia do Banco do Brasil, pouco satisfeita com sua perda de prerrogativas: "na época da criação do Banco Central 
houve um certo mal-estar no Banco do Brasil, porque ele perderia as faculdades que tinha como misto de banco central e banco comercial" ${ }^{7}$.

Ao mesmo tempo, porém, em que perdeu importantes atribuições com a reforma bancária de 1964, o Banco do Brasil ligou-se ao Banco Central através de uma conta - conhecida como "conta-movimento" - criada para registrar as atividades entre as duas instituições. Segundo Pedro Malan,

Essa conta deveria ser "zerada" semanalmente com o pagamento de $1 \%$ de juros sobre o saldo. Isto na verdade nunca aconteceu. A "conta-movimento" ajustou-se sempre passivamente à transferência de recursos para o Banco do Brasil, tal como requerida para que este cumprisse as metas de empréstimos estabelecidas pelo governo através do Conselho Monetário ${ }^{8}$.

A esse respeito, Paulo Lira, membro do grupo sumoqueano que ocupará a Presidência do Banco Central do Brasil durante a Presidência de Ernesto Geisel, nos explica que:

A compatibilização disso era feita através da ideia do Orçamento Monetário, que era preparado no Banco Central, no qual se inseriam, como uma das atividades principais, as atividades de empréstimo do Banco do Brasil. Então você tinha que estabelecer limites à atuação, à expansão do Banco do Brasil. Isso, realmente, sempre gerou um certo atrito, digamos assim, permanente, entre as duas instituições, que dependiam muito da orientação geral da política, não é? Mas o instrumento para realizar essa compatibilização da atuação do Banco do Brasil e da atuação do Banco Central era o orçamento monetário, que era aprovado pelo Conselho Monetário Nacional onde o próprio Banco do Brasil também sentava ${ }^{9}$.

O fato é que essa "conta-movimento" anulava, na prática, a autonomia do Banco Central, que se via incapaz de promover políticas monetárias verdadeiramente restritivas ${ }^{10}$. Esse entrelaçamento de funções foi mantido ainda por cerca de duas décadas, terminando somente em 1986, no governo José Sarney, quando foi encerrada a conta-movimento e retiradas do Banco do Brasil suas atribuições de autoridade monetária.

Para além da transformação da Sumoc em Banco Central - que, por si só, representou importante passo no processo de autonomização e fortalecimento dos instrumentos de gestão monetária no país -, foi conce- 
bida uma fórmula que visava a conceder autonomia mais efetiva ao Banco Central. Para tanto, seus dirigentes foram providos de mandatos fixos - não podendo ser demitidos ad nutum -, cuja duração era maior que o do presidente da República. Bulhões nos explica o princípio da autonomia do Banco Central, baseado no mandato de seus diretores:

A independência poderia ser garantida por meio da estabilidade dos diretores. Foi nesse sentido que se estabeleceu um esquema de nomeações de diretores de modo que eles fossem designados pelo governo passado, pelo governo presente e pelo governo futuro. Todos tinham o prazo de seis anos, mas uns a começar no ano $\mathrm{X}$, outros no ano $\mathrm{X} 1$, outros no ano X2, e assim por diante. Assim, diferentes governos participariam das nomeações, e nenhum deles teria maioria na designação dos diretores ${ }^{11}$.

Quanto ao Conselho Monetário, em sua primeira fase, contava com nove membros com direito a voto, dos quais um número considerável - quatro - eram diretores do Banco Central, preocupados, portanto, com a manutenção da estabilidade monetária. Além disso, o fato de possuírem mandatos de seis anos garantia sua atuação, inclusive durante o governo seguinte ${ }^{12}$.

Principal instância de formulação e coordenação das políticas monetária, creditícia, fiscal e da dívida pública interna e externa do país, o Conselho Monetário tinha, portanto, entre suas atribuições, estabelecer os limites de atuação tanto do Banco do Brasil, como do Banco Central - instituições que se restringiam a ser agentes executivos de suas deliberações.

A partir dessa primeira formulação, o Conselho sofreu tantas modificações - não só nas suas atribuições como também na composição de seus membros - que sua importância na promoção da política monetária nacional nos diferentes governos militares e, posteriormente, nos civis foi bastante irregular, o que consequentemente alterou não só a vocação, como também a função e o nível de autonomia de que desfrutou o Banco Central.

A primeira modificação ocorreu já na primeira "passagem de guarda" do Regime Militar, quando a política econômica restritiva praticada pelo governo Castelo Branco é substituída por uma outra de crescimento acelerado, adotada pelo governo Costa e Silva. Diante desse 
novo diagnóstico e desses novos desafios, as atribuições e a importância das instituições econômicas também mudaram, o que gerou conflito entre as duas equipes de governo, levando a que toda a Diretoria do Banco Central nomeada por Castelo Branco pedisse demissão. Casimiro Ribeiro, então diretor da instituição, ao ser perguntado se houve ruptura por ocasião da passagem dos governos, respondeu, sem rodeios: "Houve um trauma"13.

A implantação do sistema de rotatividade de diretores implantado pelo governo Castelo Branco havia criado problemas para o recém-empossado presidente Costa e Silva, que desejava modificar toda a equipe econômica de seu antecessor. Dênio Nogueira, presidente do Banco Central no período Castelo Branco e, portanto, com presença central nessa disputa, acusa a nova situação pelo fracasso em tornar o Banco Central numa instituição autônoma. Para Nogueira, "os inspiradores do presidente seguinte, Marechal Costa e Silva, perceberam que um Banco Central independente poria fim à política de transferência de recursos da sociedade para a oligarquia através dos subsídios geradores do déficit público"114.

Em outra entrevista, continua Nogueira, "Se o Banco Central não for independente, será, automaticamente, instrumento de poder dos políticos eventualmente no governo em benefício de seus próprios interesses e da oligarquia a que pertençam ou representem" ${ }^{\prime 15}$.

Casimiro Ribeiro, um dos diretores demissionários, confirma as dificuldades nessa passagem de governo:

Em relação a nossa atitude, mandamos dizer ao Delfim que não iríamos pedir demissão. E o Delfim, cheio de dedos porque ia ser ministro pela primeira vez, veio falar conosco e disse: "Estou muito constrangido, porque a decisão política é mudar todo mundo". Era mudar. Foi o Delfim que me disse, constrangido [...]. Num período militar o Sr. Costa e Silva entrou com uma gana em cima do governo Castelo Branco, como se fosse um governo de oposição, dos velhos tempos, compreendeu? Incrível. [...] Mas havia um aspecto formal, tínhamos de preservar o princípio de que o Banco Central tem uma administração independente, que cumpre os seus mandatos. Só interrompe o mandato se for um processo por crime, comprovado [...]. Eles sugeriram, informalmente, que nós pedíssemos demissão. A renúncia do cargo, porque nós não podíamos ser demitidos pela lei [...]. Levamos nossa resistência até um 
certo ponto, temendo poder até prejudicar o Banco Central como instituição ${ }^{16}$.

A esse respeito, Roberto Campos, ministro do Planejamento de Castelo Branco, narrou, em suas memórias, um episódio que exemplifica bem a mudança de postura em relação ao papel do Banco Central por parte do novo governo:

Dois meses antes da transmissão de poder fui, como ministro do Planejamento, instruído por Castelo Branco para explicar ao presidente eleito, Costa e Silva, os capítulos econômicos da nova Constituição de 1967. Aproveitei para sugerir-lhe que pusesse termo aos boatos de substituição do presidente do Banco Central, pois a lei lhe dava mandato fixo, precisamente para garantir estabilidade e continuidade na política monetária.

- O Bacen é o guardião da moeda - acrescentei.

- O guardião da moeda sou eu - retrucou Costa e Silva.

Foi inútil tentar persuadi-lo de que nem o Legislativo nem o Executivo costumam portar-se heroicamente na luta anti-inflacionária, pois ambos são sujeitos a enormes pressões de gastança, que recrudescem nos anos eleitorais. Costa e Silva ignorou os mandatos, e Delfim Netto, o novo ministro da Fazenda, não tinha fanatismo pela ideia de independência do Banco Central. (Campos, 1994:669)

Finalmente, após algumas negociações, e em função das pressões vindas da nova situação, a Diretoria do Banco Central, temendo criar um cenário de confronto mais grave, resolveu renunciar, decisão que, segundo Casimiro Ribeiro, foi tomada com o intuito de evitar futuras retaliações por parte do novo governo à instituição:

Nosso receio era o de que de nossa intransigência podia vir até uma mudança de lei. O que infelizmente foi feito, não pelo Delfim, mas pelo Mário Henrique Simonsen. Essa resistência calou fundo em alguns militares. O Mário Henrique assumiu em 15 de março e, no começo de maio, ele levou um projeto de lei ao Geisel - recebeu instruções para isso, evidentemente - fazendo as seguintes modificações na estrutura legal: os diretores do Banco Central são nomeados pelo presidente da República, sem audiência do Congresso. Não têm mandato certo e são demissíveis ad nutum, e não têm mais quatro votos no Conselho Monetário. Apenas o presidente tem voto ${ }^{17}$. 
Voltando ao governo Costa e Silva e a esse contexto de mudança na orientação econômica, uma quantidade enorme de atribuições foi transferida para o Conselho Monetário, que passou a se dedicar à política econômica como um todo, perdendo foco as atribuições relativas ao controle da inflação e perdendo autonomia o Banco Central.

O Conselho passa, a partir de então, a ter dez membros com direito a voto (Lei no 5.362/67) e aumenta de seis para sete o número de membros escolhidos pelo presidente da República devido ao acréscimo de mais um diretor ao Banco Central. Além disso, os membros escolhidos, a partir de então, não precisariam mais da aprovação do Senado Federal, passando a ter mandatos de sete anos. Nessa época, o Banco Central amplia mais suas atribuições, tornando-se, também, responsável pela fiscalização do Mercado de Capitais.

A partir de dezembro de 1969, já no governo Médici, o Conselho passa a contar com quatorze membros (Decreto no65.769/69). Passam a compor este Conselho os ministros do Interior e da Agricultura, sendo que os ministros do Planejamento e da Indústria e Comércio, antes sem direito a voto, passam a tê-lo. Além disso, os membros indicados pelo presidente tiveram seus mandatos reduzidos para quatro anos.

Essa nova situação amplia o poder do ministro da Fazenda, que passa a administrar a economia nacional através do Conselho, que ele preside, e do Banco Central, que segue suas determinações.

Também foi aumentado o poder do Conselho sobre todas as instituições financeiras que ficaram obrigadas, a partir de então, a remeter ao Banco Central, até o dia 30 de novembro de cada ano, o orçamento de recursos e aplicações para o exercício seguinte, devendo este enviá-lo para a devida aprovação do Conselho. As atribuições e poderes do Conselho aumentam ainda mais quando este se torna responsável pela política nacional de abastecimento, transformando a Superintendência Nacional de Abastecimento (Sunab) em simples fiscalizadora dessa política.

A partir de 1972, ainda no governo Médici, o Conselho Monetário consolida definitivamente sua nova condição de órgão coordenador de toda a política nacional com a inclusão, em seu quadro, dos presidentes do Banco Nacional da Habitação (BNH) e da Caixa Econômica Federal (CEF) (Decretos no 65.769/72 e no 71.097/72). No rol dos membros com direito a voto contam-se, agora, dezesseis conselheiros. 
Coroando essa nova arquitetura, o Banco Central passa a ter uma diretoria composta de cinco membros, todos com direito a voto no Conselho, adquirindo, portanto, a maioria em suas decisões. Converte-se, assim, em instituição reguladora de toda a política econômica nacional ${ }^{18}$.

O Conselho Monetário deixou de ser, então, durante os anos do "milagre econômico", instituição orientada essencialmente para o controle da inflação. Estava a serviço do Poder Executivo, que passou a utilizá-lo, entre 1967 e 1973 (período Delfim Netto), não só como autoridade monetária, mas como instrumento de promoção do crescimento da economia, tornando-se instância máxima de coordenação de toda a atividade econômica do país.

Nesse novo cenário, o governo Geisel, ao tomar posse, promove mudanças radicais na estrutura do Conselho, que considerava estar concentrando demasiadas prerrogativas ${ }^{19}$. Esse "estilo" centralizador de Geisel resultou na redução dos membros do Conselho Monetário, passando de dezesseis para dez (Lei no 6.045/74) e, em seguida, para onze membros (Lei no 6.385/76) e, também, na perda de mandatos protegidos dos diretores do Banco Central. Estes passam a ser, então, nomeados diretamente pelo presidente da República, podendo ser demissíveis ad nutum. Além disso, somente o presidente do Banco Central passou a ter voto no Conselho.

Se, em um primeiro momento, em um cenário voltado para a estabilização da moeda, o governo Castelo Branco cria o Banco Central e o Conselho Monetário Nacional como instituições fortes e autônomas, em um segundo momento, durante os governos Costa e Silva, Médici e Geisel, estas mesmas instituições submetem-se ao governo e passam a promover uma política de crescimento econômico.

O governo Figueiredo, cuja principal missão política era realizar a transição democrática, inaugura uma tentativa de retomada do Conselho Monetário Nacional como instância de deliberação e coordenação da política econômica, procurando dar maior espaço para a participação de membros da iniciativa privada. Como visto, tanto o número de membros do Conselho com direito a voto, quanto os anos de seus mandatos, variaram no tempo. Em seu início, durante o governo Castelo Branco, eram 9 os seus membros e tinham seis anos de mandato. No governo Figueiredo, último do período militar, eram 24 os seus membros com mandatos de cinco anos (Decreto no 85.776/81). 
O governo Figueiredo foi o que enfrentou os piores momentos da crise iniciada nos anos de 1970. Ao descontrole da inflação, que se agravou vertiginosamente, juntaram-se a crise do mercado internacional, causada pela moratória mexicana, uma grande desarticulação das instituições públicas nacionais e, em particular, a falta de identidade das instituições monetárias que se encontravam sem papel definido e enfraquecidas.

Nessa circunstância, Ernane Galvêas, presidente do Banco Central dos governos Costa e Silva e Médici, e ministro da Fazenda do governo Figueiredo, justifica sua posição contra a autonomia do Banco Central chamando a atenção para sua descaracterização, já que tinha se transformado em detentor de múltiplas atribuições.

O muito que você poderia esperar é que o Banco Central tivesse duas funções: a de Banco Central propriamente dito - banco central puro-,e mais a fiscalização do sistema. Mas aqui não. Ele entrou fiscalizando o mercado de capitais, as bolsas de valores, o capital estrangeiro, o crédito rural... Então, é uma instituição que não é um banco central, é muito mais que um banco central. É por isso que, quando as pessoas começam a falar em independência do Banco Central, eu acho até um pouco engraçado. Por que dar independência a um banco central com essas atribuições todas? [...] Não há presidente da República, nem primeiro-ministro, nem ministro da Fazenda que vá reunir os mesmos poderes que teria o presidente do Banco Central. Imagina um presidente de banco central com absoluta autonomia e independência, com esse Banco Central que está aí. Agora ainda tem a Comissão de Valores Mobiliários, tem umas outras coisas que saem do Banco Central [...]. Você pode dar independência e autonomia a uma pessoa normal, mas ao Frankenstein você não dá independência nem autonomia, ele tem que ser teleguiado. Se não, pode ser um desastre ${ }^{20}$.

A partir dos anos 1970, os choques do petróleo e dos juros internacionais e a redução dos fluxos financeiros foram, gradativamente, alterando as bases da bem sucedida condução da política monetária do pós-guerra. A maioria dos países do mundo ocidental passa por uma piora drástica no que diz respeito às condições que então permitiam que se perseguissem o pleno emprego e o crescimento econômico. Inicia-se um outro ciclo, inflacionário e de menor crescimento econômico. Nesse novo contexto, a regulação das taxas de juros pelas autoridades monetárias passou a significar uma escolha trágica entre controlar a inflação ou manter o foco na manutenção do crescimento econômico e do 
pleno emprego, situação que intensificou a discussão política sobre a concessão de autonomia para os bancos centrais.

É necessário considerar que essas transformações ocorreram em um momento de transição entre um mundo nacional e um outro, global, e desafortunadamente o Brasil ingressava nessa nova etapa da economia mundial pela tortuosa porta da hiperinflação e da dívida pública. Nesse novo mundo, os bancos centrais passaram a desfrutar de mais importância e mais autonomia, não só econômica, como também política, em virtude da inédita ascendência que o capital financeiro passou a ter, tanto sobre o financiamento da iniciativa privada, como dos próprios Estados nacionais constrangidos por crises fiscais e políticas.

Essa situação é transferida, em sua essência, para o governo de José Sarney, que inaugura o primeiro de uma série de planos que visaria a combater o que havia se tornado um dos principais problemas da economia nacional: a inflação. Nesse ambiente, o Banco Central do Brasil volta a ocupar um lugar de destaque, participando de uma série de experimentos que culminaram (nos governos Itamar Franco e Fernando Henrique Cardoso) em um plano vitorioso de combate à inflação.

No período presidencial de Sarney, o Conselho Monetário sofre novos acréscimos com a inclusão dos ministros do Trabalho, e do Desenvolvimento Urbano e Meio Ambiente, além de mais dois membros, sendo um representante da classe trabalhadora, todos com direito a voto. Varia seu colegiado, nesse período, entre 26 e 27 membros $^{21}$.

Em razão de uma composição ministerial realizada em meio a um delicado processo de redemocratização política, as equipes do Ministério da Fazenda e do Banco Central do governo Sarney tinham orientações distintas, o que criava divergências a respeito dos procedimentos a serem adotados, situação que reduziu consideravelmente a autonomia do Banco Central. Fernão Bracher, ao ser perguntado se o Banco Central, que presidiu de agosto de 1985 a fevereiro de 1987, tinha autonomia, respondeu claramente que não, e que a última palavra acabava sendo a do então ministro da Fazenda, Dilson Funaro, que "era assessorado sobretudo pela equipe de Campinas, pelo João Manuel (Cardoso de Melo) e pelo (Luiz Gonzaga) Belluzzo, que se guiavam por linhas totalmente diferentes. Outras percepções. [...] Eu consegui, em determinado momento, uma pequena desvalorização cambial e isso causou uma grande celeuma lá na equipe do Ministério da Fazenda"22. 
Nesse período, o Conselho Monetário passa a ser uma instância meramente homologatória do Ministério da Fazenda. O Banco Central, por sua vez, encontrava-se descaracterizado se se considerassem as funções que a reforma bancária do governo Castelo Branco havia lhe atribuído, tendo sido transformado em um banco voltado mais para a administração da economia nacional.

Francisco Gros, que sucedeu a Bracher na Presidência do Banco Central, testemunha nesse sentido.

Em 1987 (Sarney) as reuniões se davam numa sala com 30, 40 pessoas. Todos os membros com direito a voto. Só que, a rigor, com essa composição era um instrumento homologatório das decisões do Banco Central combinadas previamente com o Ministério da Fazenda. [...] O governo votava em bloco. Toda essa turma seguia o voto do chefe. $\mathrm{Ou}$ você acha que o presidente do Banco do Brasil iria votar diferente do ministro da Fazenda? Todo mundo votava igual. Então, era absolutamente homologatório. Volta e meia, os representantes da iniciativa privada levantavam alguma coisa. Mas para ter alguma chance de sucesso, teria que ser combinado antes. Então, nesse fórum: zero de decisão. Hoje, não, o Conselho Monetário Nacional, com 3 membros, tem espaço para debater e discutir efetivamente. Mas um fórum de 30, 40 pessoas, nenhuma chance. O Conselho Monetário não era um fórum importante nessa época ${ }^{23}$.

Apesar da ambiguidade vivida pelo governo Sarney, algumas medidas significativas foram adotadas no sentido de ampliar a autonomia do Banco Central do Brasil, sendo a mais importante a extinção da conta-movimento, em 1986, retirando do Banco do Brasil suas atribuições de autoridade monetária ${ }^{24}$.

Com o término do governo Sarney foi eleito para a Presidência da República Fernando Collor de Mello, em cuja administração diminuem os membros do Conselho Monetário para 16 (Decreto no 99.207/90), aumentando posteriormente, para 17 (Lei no 8.056/90) componentes.

Collor, ao escolher Ibrahim Eris para presidir o Banco Central, a ele delegando a incumbência de montar, sem interferência sua, a equipe com a qual iria trabalhar, estava indicando que o Banco seria independente. Para Eris, a autonomia do Banco Central à época em que o presidiu,

foi de $100 \%$. Isso não quer dizer que eu nunca sentei na frente do presidente ou da Zélia (Cardoso de Mello, ministra da Fazenda) para dar sa- 
tisfação a eles. Mas em nenhum momento foi num sentido de cobrança. Eu tenho certeza que agi no Banco Central, posso dizer, com total liberdade. Como em qualquer país, os bancos centrais são agentes políticos também, eles não são $100 \%$ técnicos. Logo, eu não estou dizendo aqui que todas as decisões foram $100 \%$ técnicas. Não, obviamente. Você tem que considerar as condições políticas e sociais do momento, mas eu agi com total liberdade. Eu acho que fui o primeiro presidente do Banco Central a agir como tal, isso porque a Zélia confiava em mim, eu acho, e o presidente também ${ }^{25}$.

Com o fracasso dos planos econômicos do governo Collor e com as adversidades políticas a que estava sendo submetido, a equipe econômica é trocada. Vai para o Ministério da Fazenda Marcílio Marques Moreira e, para o Banco Central, Francisco Gros, que já havia ocupado a Presidência da instituição no governo Sarney. Sua opinião sobre o Conselho era que o mesmo continuava, como à sua época, a ter um caráter homologatório, talvez atenuado em 1991 e 1992, pelo fato de o novo ministro ter convidado,

por sugestão de todos nós, gente de peso da iniciativa privada para participar. Ele convidou setores representativos, o Roberto Rodrigues, atualmente ministro da Agricultura; o Paulo Cunha, empresário de peso; o Arthur Sendas, para dar uma visão do comércio; o Alcides Tápias, para dar uma visão do setor financeiro, ou seja, gente que tem opinião própria. Aí, pela própria natureza do Marcílio, havia um pouco mais de espaço para debate. Eu me lembro de alguns casos em que as pessoas traziam ponderações e dizíamos: "Tem razão, vamos pensar em algo e mês que vem a gente traz de volta." Mais uma vez, entretanto, pela vontade do príncipe e não pela natureza da instituição ${ }^{26}$.

Com a renúncia de Collor e a posse de seu vice, Itamar Franco, a autonomia reivindicada pelo Banco Central, que ressurgia com mais força, torna-se objeto de desconfiança e de preocupação por parte do governo. Sobre o período inicial do governo Itamar Franco é expressivo o depoimento de Francisco Gross, que foi presidente do Banco por apenas 45 dias.

Em relação ao presidente Itamar, uma das razões que eu achei importante sair, independentemente de qualquer outra coisa, era exatamente o fato de que ele emitia sinais de descrença nesse modelo de independência. Não só no nível do Banco Central, mas em relação ao Ministério da Fazenda também. Ele tinha uma visão muito intervencionista, mar- 
cada por intervenções pontuais. O ministro da Fazenda com quem convivi, o Gustavo Krause, teve, por exemplo, um problema em relação a um aumento de leite - um procedimento altamente rotineiro, decidido quatro escalões abaixo do ministro. O presidente Itamar decidiu intervir e arrumou uma quizumba porque tinham aumentad o o preço do leite sem consultá-lo. Então, claramente a sinalização era que ele não concordava com esse modelo. Eu tenho uma visão diferente. Acho que o Banco Central tem que ter missões muito claramente definidas e restritas. Dentro dessas missões ele deve ter liberdade para executar a missão que lhe foi confiada pela sociedade $[\ldots]^{27}$.

Para Francisco Gros o presidente Itamar, notoriamente, enxergava o Banco do Central como uma caixa-preta que deveria ser administrada de perto.

Era contrário a qualquer tipo de independência ou autonomia. A visão dele era absolutamente contrária à nossa, que entendíamos que o Banco Central deveria ser administrado tecnicamente e longe de intervenções políticas do presidente da República. A visão do presidente Itamar não é diferente da de muita gente, de muitos políticos, mas era muito diferente da nossa. Então, nós tínhamos o sentimento de estar ali com uma bomba-relógio ${ }^{28}$.

Em razão dessa convicção, "nós todos combinamos uma estratégia de saída escalonada onde sairia um de cada vez. Fui o primeiro, depois o Armínio (Fraga), depois o Pedro Bodin. O Gustavo Loyola que era amigo de todos nós, ficou na Presidência" ${ }^{29}$.

Na verdade, Loyola fica na Presidência do Banco Central por apenas quatro meses, saindo ao mesmo tempo em que o ministro da Fazenda, Paulo Haddad, foi substituído. É interessante notar que, na narrativa de Gros, esse mesmo dilema relativo às relações do Banco Central com o mercado e com o Estado ressurgia na convicção do presidente de que o Banco Central deveria ser administrado por funcionários de carreira.

Tanto que depois de minha saída ele convidou o Gustavo Loyola. Depois nomeou o presidente do Banco do Brasil, o (Paulo César) Ximenes, que também era funcionário de carreira. Nomeou de novo o Gustavo Loyola e depois nomeou o Pedro Malan - que não era um funcionário de carreira do Banco Central, mas era muito ligado à instituição. Enfim, ele não se sentia muito confortável com gente vinda da iniciativa priva- 
da nesse tipo de organização. Ele nunca me disse isso pessoalmente, mas é uma posição histórica e conhecida dele ${ }^{30}$.

Sobre o Conselho Monetário, o número de seus participantes aumenta, inicialmente, para vinte (Lei no 8646/93), diminuindo, posteriormente, para três (Medida Provisória 542/94). No primeiro período, têm assento no Conselho, além dos ministros da Fazenda, do Planejamento e do presidente do Banco Central, vários outros ministros, cinco representantes da iniciativa privada, e mais cinco presidentes de bancos federais que eram, contraditoriamente, fiscalizadores e fiscalizados em suas atividades. No segundo momento, fizeram parte do Conselho apenas os ministros da Fazenda, do Planejamento e o presidente do Banco Central ${ }^{31}$.

Gustavo Franco, que foi diretor da área externa do Banco Central do Brasil no período presidencial de Itamar Franco, e seu presidente durante parte do primeiro mandato de Fernando Henrique, nos dá um testemunho eloquente sobre os procedimentos que permitiram a reconquista da autonomia por parte do Banco Central e do Conselho Monetário Nacional.

Nós criamos uma coisa que modestamente eu acho muito engenhosa no sentido de proteger a área econômica da influência da área política. [...] Nós não podíamos mexer na lei 4595 porque era uma lei complementar. Também não podíamos mudar a competência do Conselho Monetário. Mas podíamos mudar sua composição.

O Conselho Monetário tinha 20 pessoas. Tinha os 3 membros de hoje e mais uma penca de ministros. 5 representantes da iniciativa privada, 5 presidentes dos bancos federais. E a Comissão de Economia do Senado queria um representante, o Ministério Público queria um representante e também os bancos estaduais. Então, na verdade (o Conselho) deixou de ser técnico. Era uma assembleia e a política monetária não se resolve em assembleia. Não apenas pelos vícios de qualquer assembleia, mas pelo fato de que ali você tem um regulador e você tem regulados sentados dentro do Conselho. Quer dizer, o Banco do Brasil é uma entidade regulada, supervisionada pelo Conselho, como é que ele está sentado ali? Que história é essa? Não pode. A iniciativa privada (também) não era para estar ali. Bem, o que a gente fez foi reduzir o Conselho Monetário para 3 membros o que o despolitizou praticamente por inteiro. Ali tem o Planejamento, a Fazenda, que sempre foi uma relação tensa, mas tem o Banco Central que desempata. Então, se criou na verdade um me- 
canismo de resolução de conflito histórico entre a Fazenda e o Planejamento muito simples ${ }^{32}$.

A implementação das Medidas Provisórias, o surgimento do Real e a desvinculação do Conselho Monetário da Presidência da República, fazendo com que ele voltasse a ter independência para desempenhar atribuições de combate à inflação, não poderiam deixar de ser povoadas de tensões e conflitos. Certa ocasião, no calor das negociações envolvendo a equipe econômica e a Presidência da República, foi levada ao presidente Itamar Franco a proposta de um Conselho com apenas dois membros.

O Itamar não gostou desse negócio de fazer um conselho de 2, e para aceitar 3 fez duas exigências: a primeira foi criar uma coisa chamada COMOC que é [...] menos comentada, mas importantíssima [...] e acabou sendo criada quase por acidente. [...] Tudo antes de ir para o Conselho Monetário passa pela COMOC. [...] Então era uma maneira de você criar um anteparo, uma espécie de guarda pretoriana entre a Diretoria do Banco, a Caixa e o Banco do Brasil. [...] A COMOC são 3 diretores do Banco Central, o presidente do CVM e 3 secretários, 2 da Fazenda e um do Planejamento. Se reúnem, onde o COPOM também se reúne, cada um leva sua entourage. Só técnico. Tem uma pauta, todos os votos são contados, todo mundo recebe com antecedência ${ }^{33}$.

Sobre o Copom ${ }^{34}$ (Comitê de Política Monetária), que completou a engenharia institucional de apoio à nova moeda, o Real, "nada mais é que uma seção especial da Diretoria do Banco Central. [...] A criação do COPOM foi uma espécie de ato da própria Diretoria do Banco Central. [...] Nós vamos nos reunir mensalmente só para falar de política monetária e deliberar sobre a taxa de juros" ${ }^{\prime 35}$.

No governo Fernando Henrique Cardoso, em continuidade ao que já vigorava no final do governo Itamar Franco, o Conselho continuou com três membros (Lei no 9.069/95) adquirindo poder decisório e direcionando suas atividades para a manutenção do sucesso do Plano Real. Deve ser ressaltado, no entanto, que, apesar da autonomia de fato desfrutada pelo Banco Central nos dois mandatos de Fernando Henrique Cardoso, por ocasião da crise cambial de 1998 é afastado do cargo Gustavo Franco, então presidente da instituição, por discordar da intenção do governo em adotar o câmbio flutuante - sistema que passou a vigorar após a sua saída do Banco. 
Finalmente, devem ser ressaltadas as tendências à maior concessão de autonomia legal ao Banco Central contidas na Constituição de 1988 que, apesar de atribuir ao presidente da República a indicação dos seus dirigentes, e dos mesmos ainda serem demissíveis ad nutum, reserva ao Senado Federal a aprovação de tais indicações. No entanto, a Constituição não prevê nenhum mecanismo formal de prestação de contas do Banco Central ao Congresso Nacional (Santos e Patrício, 2002).

A Constituição, em seu artigo 164, também proíbe que o Banco Central financie o Tesouro Nacional, ou qualquer órgão, ou entidade que não seja instituição financeira, o que não deixa de reforçar a autonomia do Banco Central. Outras alterações institucionais importantes, que garantem maior autonomia ao Banco Central do Brasil, foram a criação do Copom e a adoção do sistema de metas inflacionárias ${ }^{36}$. A partir dessas duas inovações, procurou-se formalizar a função estabilizadora do Banco Central, confirmando sua autonomia operacional para perseguir as metas de inflação estabelecidas pelo Conselho Monetário Nacional.

\section{CONCLUSÃO}

Para concluir, voltemos nosso olhar para a argumentação central contida na Introdução do presente artigo, segundo a qual a estabilidade da moeda nacional depende, para além do equilíbrio das contas públicas e da autonomia da Sumoc e do Banco Central, também da estabilidade política e institucional dessas instituições. Esta estabilidade aqui se traduz por baixas taxas de circulação dos membros da equipe econômica (ministros da Fazenda, superintendentes da Sumoc e presidentes do Banco Central) como também pela composição de conselhos monetários menos numerosos e, consequentemente, mais impermeáveis a demandas clientelísticas ${ }^{37}$.

Afirmamos, também, que as autonomias tanto da Sumoc, quanto do Banco Central do Brasil, passaram por diferentes fases, variando, sobretudo, em relação ao aspecto cíclico da economia brasileira que, ao ter alternado políticas desenvolvimentistas com políticas estabilizadoras, alterou, consequentemente, a vocação e o grau de autonomia da Sumoc e do Banco Central. Assim, os períodos desenvolvimentistas foram caracterizados por altas taxas de crescimento da economia, por menor autonomia da Sumoc e do Banco Central, e por conselhos monetários mais numerosos. Por sua vez, os períodos de estabilização recla- 
Instituições Fortes, Moeda Estável e Banco Central do Brasil Autônomo

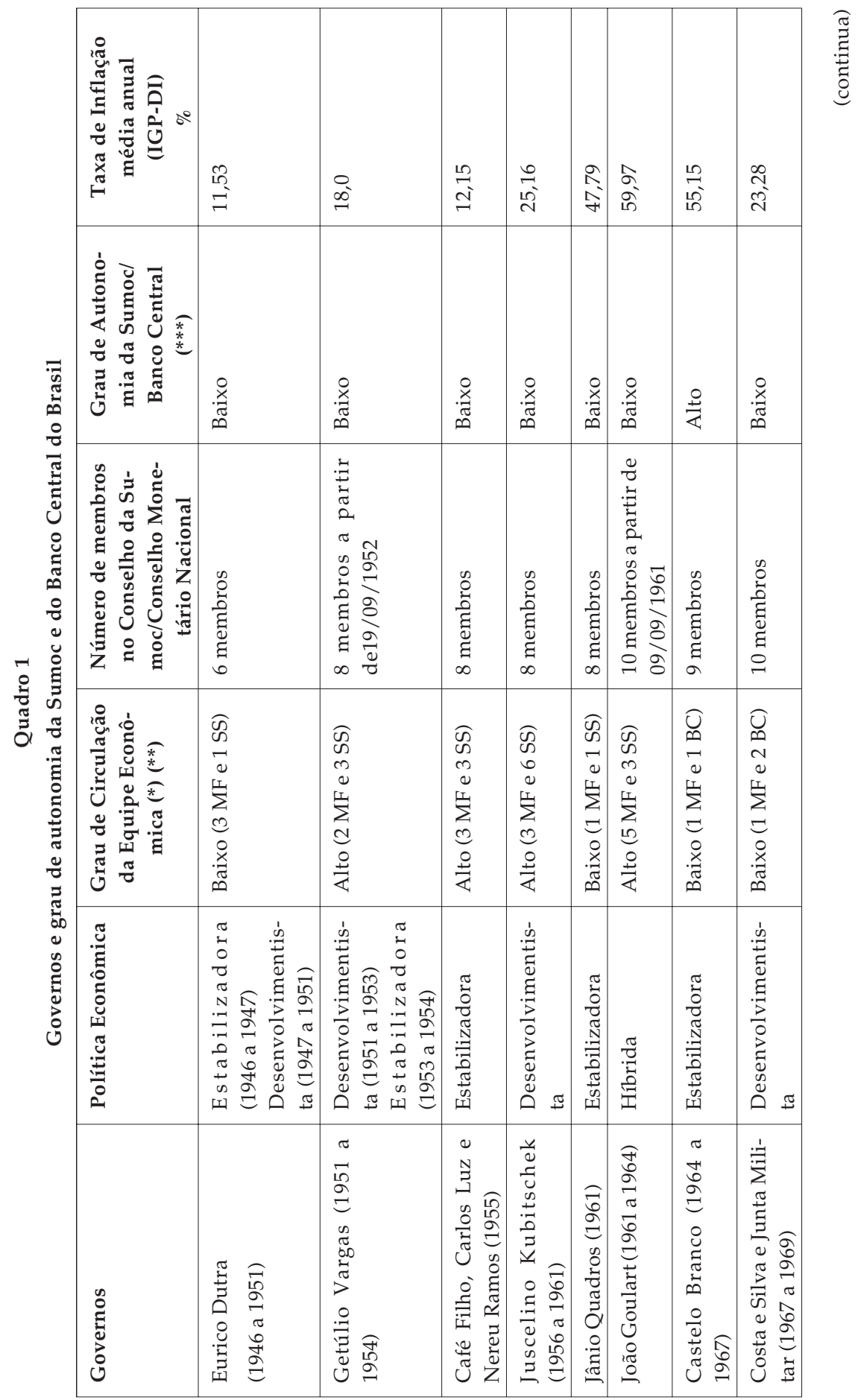




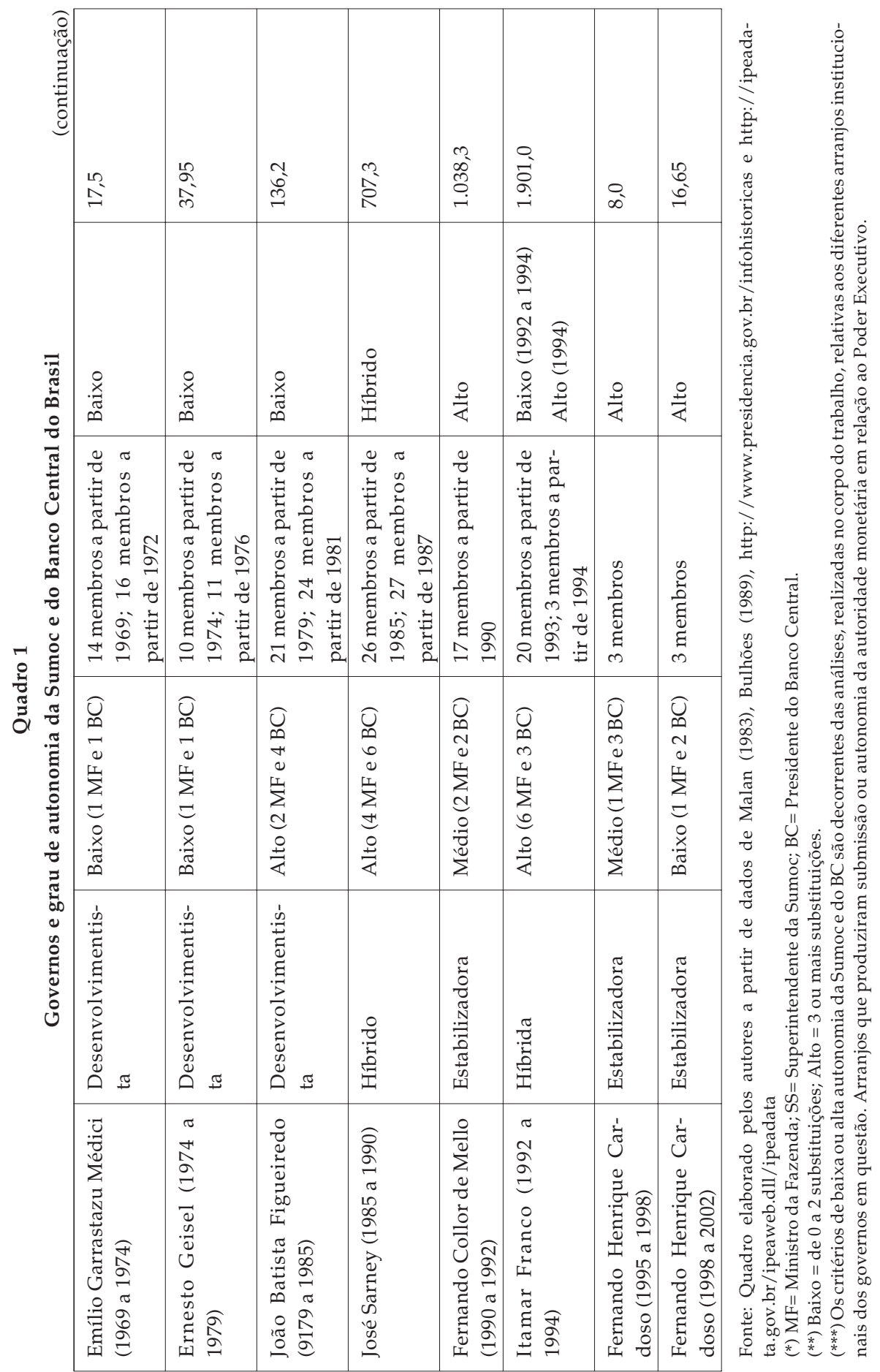


maram bancos centrais mais autônomos e conselhos menos numerosos para enfrentar conjunturas de desequilíbrio fiscal e de altas taxas de inflação.

Com a ajuda do Quadro 1, que resume os pontos da argumentação proposta, as seguintes correlações podem ser feitas.

1) Quanto à Sumoc, nunca desfrutou realmente de autonomia, nem de fato nem de direito, tendo sido subordinada, em maior ou menor grau, ao Banco do Brasil, ao Ministério da Fazenda e ao próprio Conselho da Sumoc, tanto em períodos desenvolvimentistas quanto estabilizadores.

2) Quanto ao Banco Central, sua autonomia variou de acordo com a política econômica praticada pelos diferentes governos aos quais esteve ligado. Se o governo foi desenvolvimentista sua autonomia foi mais baixa. Este foi o caso dos governos Costa e Silva, Médici, Geisel e Figueiredo, ou seja, 100\% dos casos.

3) Contrariamente, quando o governo foi estabilizador a autonomia do Banco Central foi mais alta. Caso dos governos Castelo Branco, Collor de Mello e dos dois períodos presidenciais de Fernando Henrique Cardoso, ou seja, 100\% dos $\operatorname{casos}^{38}$.

4) Os governos que adotaram políticas econômicas híbridas foram João Goulart, José Sarney e Itamar Franco.

- No curto período governamental de João Goulart a política econômica adotada foi considerada híbrida em razão de o Plano Trienal coordenado por Celso Furtado ter estabelecido não apenas diretrizes desenvolvimentistas, como também monetárias, contribuição esta realizada por Casimiro Ribeiro, funcionário da Sumoc.

- No caso do governo Sarney, tanto a política econômica quanto o grau de autonomia do Banco Central foram considerados híbridos. Isto porque, apesar do Bacen ter ocupado lugar de destaque no primeiro de uma série de planos de estabilização monetária realizados no país, a equipe econômica do Ministério da Fazenda era de orientação desenvolvimentista, o que criou divergências a respeito dos procedimentos a serem adotados para combater a inflação, limitando a autonomia da autoridade monetária.

- O governo Itamar Franco pode ser melhor compreendido se o mesmo for dividido em duas fases. Na fase inicial, de 1992 a 1994, a política econômica praticada tinha um cunho mais desenvolvimentista tendo tido o Banco Central baixa autonomia. Na segunda fase, de 
1994 em diante, a política econômica, bem mais comprometida com o Plano Real, era francamente estabilizadora, tendo sido alta a autonomia do Banco Central.

5) Quando houve alta circulação da equipe econômica houve, também, viés de alta da taxa de inflação em relação ao governo anterior. Assim sendo, dos governos com alto grau de circulação (Vargas, Café Filho, Kubitschek, Goulart, Figueiredo, Sarney e Itamar), o viés de alta atingiu os governos Vargas, Kubitschek, Goulart, Figueiredo, Sarney e Itamar), ou seja, 6 dos 7 governos .

6) Porém, quando houve baixo grau de circulação da equipe econômica (J. Quadros, Castelo Branco, Costa e Silva, Médici, Geisel, Collor, FHC1 e FHC2), não houve uma tendência expressiva de viés de baixa na inflação, que só atingiu os governos Castelo Branco, Costa e Silva, Médici e FHC1, ou seja, apenas 4 dos 8 governos em questão.

7) Ou seja: Quando há alta circulação da equipe econômica, há uma correlação clara e positiva de viés de alta da inflação. Porém quando há baixa circulação da equipe econômica não significa que haja, necessariamente, viés de baixa na inflação.

8) As cinco exceções são expressivas e as circunstâncias onde ocorreram podem ajudar a compreendê-las. São elas:

- Sobre o período posterior ao suicídio de Vargas, é necessário notar que foi fortemente conturbado do ponto de vista político e institucional, tendo havido entre agosto de 1954 e janeiro de 1956, três presidentes da República: Café Filho, Carlos Luz e Nereu Ramos. Nessas condições, apesar da circulação da equipe econômica ter aumentado (três ministros da Fazenda e três superintendentes da Sumoc), a taxa de inflação diminuiu, resultado das políticas estabilizadoras adotadas na segunda metade do governo Vargas e durante o governo Café Filho.

- Também deve ser relembrado que o curto governo de Jânio Quadros foi estabilizador, tendo sido realizado um início de esforço de combate à inflação. Porém, havia um processo inflacionário em curso, herdado do governo Kubitschek, que não pôde ser debelado por um governo que ficou apenas um ano no poder e em meio a inúmeras crises que resultaram na renúncia do presidente da República. Assim, apesar da circulação da equipe econômica ter sido baixa (um ministro da Fazenda e um superintendente da Sumoc), a inflação aumentou para $47,79 \%$. 
- No governo Geisel, apesar da circulação da equipe econômica ter sido baixa (um ministro da Fazenda e um presidente do Banco Central), houve elevação da taxa de inflação para 37,95\% em razão do início da forte crise econômica iniciada no mesmo ano da posse de Geisel e que chegará ao seu auge no governo Figueiredo.

- No governo Collor, apesar da circulação da equipe econômica ter sido baixa - 2 ministros da Fazenda e 2 presidentes do Banco Central - a inflação sobe dos 707,3\% registrados no governo Sarney para $1.038,3 \%$. Duas circunstâncias colaboraram para tanto: a curta duração do governo, apenas 18 meses, e os diagnósticos e prognósticos realizados ainda precários sobre as causas da inflação e a solução para debelá-la.

- No segundo governo FHC, apesar do baixo grau de circulação da equipe econômica, a inflação aumentou (de $8 \%$ para 16,65\%), influenciada pelas circunstâncias econômicas internacionais, sobretudo pela crise da Rússia. (1988).

9) É também significativo que, após a criação do Banco Central do Brasil, os governos estabilizadores e com tendência a taxas de inflação mais baixas tenham reduzido consideravelmente o número de membros de seus conselhos monetários se comparados aos governos anteriores. São os casos dos governos Castelo Branco, Itamar Franco ( $2^{\mathrm{a}}$ fase) e dos dois mandatos de Fernando Henrique Cardoso (100\% dos casos).

10) Nos governos desenvolvimentistas, ao contrário, os conselhos monetários do Bacen tiveram suas composições recorrentemente ampliadas. São os casos dos governos Costa e Silva, Médici, Figueiredo.

11) As duas exceções são os governos desenvolvimentista de Geisel e estabilizador de Collor de Mello. No primeiro caso, a diminuição do número de membros do Conselho Monetário pode ser explicada pela criação do Conselho de Desenvolvimento Econômico - instância que passa a concentrar as decisões governamentais sobre políticas públicas em geral. No governo Collor, apesar das intenções estabilizadoras, da maior concessão de autonomia ao Banco Central e da considerável redução no número de membros do Conselho Monetário, a inflação aumentou, o que pode, em parte, ser atribuído aos diagnósticos e prognósticos ainda precários sobre a inflação.

O presente artigo buscou apresentar um panorama abrangente do processo de institucionalização da autonomia da autoridade monetária brasileira. As correlações estabelecidas na conclusão tiveram sobretu- 
do a preocupação de apontar para tendências que permitissem uma leitura mais compreensiva do processo econômico nacional. Resumidamente, o que procuramos demonstrar é que a autonomia da autoridade monetária brasileira tem sido afetada historicamente 1) pelas preferências de política econômica de cada governo e 2) pelo grau de insulamento e apoio político que cada governo concedeu a sua equipe econômica. A estabilidade monetária, por sua vez, parece resultar desse apoio político, visto que, em sua ausência, a autoridade monetária tende a se subordinar às orientações do governo. Desse modo, acreditamos que não é a autonomia per se que propicia a estabilidade monetária. Em países que ainda estão consolidando seus arranjos institucionais, como o Brasil, uma condição necessária para que um banco central seja autônomo e que esse possa garantir a estabilidade monetária é o apoio político garantido pelo governo. Sem esse apoio, a autonomia, seja ela de jure ou de facto, de meios ou de fins, mostra-se extremamente frágil.

Acreditamos, assim, que uma série de questões ainda não amplamente debatidas sugerem novas pistas de pesquisa a serem exploradas em maior detalhe em trabalhos futuros como, por exemplo, o processo de saneamento dos bancos públicos estaduais ou potenciais processos de captura da autoridade monetária por interesses particulares. Outro tema interessante para ser explorado é a crescente participação do Banco Central do Brasil em organismos multilaterais como o Comitê da Basileia, tornando-o uma porta de entrada para importantes dinâmicas regulatórias do sistema financeiro global. Um outro importante caminho a ser explorado é a ampliação do escopo de nossa análise para outros países sul-americanos, a fim de compreendermos melhor as variáveis que contribuem para a manutenção da estabilidade institucional de bancos centrais. Recentes episódios na Argentina e Venezuela nos dão sinais de que a autonomia formal da autoridade monetária não é suficiente para se manter uma autonomia de facto. Por último, resta saber se a autonomia de fato do Banco Central do Brasil, mantida durante o governo Lula, representa uma tendência mais perene do sistema financeiro nacional, devido à percepção da baixa inflação como um bem público e de grande apelo eleitoral, ou esse seria apenas mais um episódio de nossa história moderna de alternância entre governos desenvolvimentistas e estabilizadores.

(Recebido para publicação em junho de 2008)

(Reapresentado em fevereiro de 2009)

(Versão definitiva em novembro de 2010) 


\section{NOTAS}

1. Essa escolha se deve ao fato de as alterações dos titulares tanto do Banco Central quanto do Ministério da Fazenda terem repercutido diretamente sobre a ruptura das políticas monetárias e creditícias praticadas no período analisado. Outra importante razão diz respeito às nomeações e demissões dos presidentes do Banco Central que, apesar de serem prerrogativas do presidente da República, normalmente eram realizadas pelos ministros da Fazenda, encontrando-se, em alguns casos, subordinados na prática a eles.

2. “Uma razão é que o efeito da política monetária sobre a produção e a inflação vem com longas defasagens; por isso, as pessoas responsáveis pela tomada de decisões não veem os resultados de suas ações por um bom tempo. Mas a outra razão, bem mais importante, é que a desinflação tem o perfil característico de custo-benefício de uma atividade de investimento: custa algo no início e apenas gradualmente, com o tempo, dá retornos" (Blinder, 1999:73).

3. Decreto-Lei $n$ 윽.293, de 2 de fevereiro de 1945. Esse decreto visava a atender às exigências impostas ao Brasil pela sua participação no tratado de Bretton Woods.

4. Grupo de grande unidade e coerência, que possuía uma visão monetarista da economia e era liderado por Otávio Gouveia de Bulhões, e que foi central para a transformação da Sumoc em Banco Central. Para conhecimento mais detalhado das ideias desse grupo, ver as teses de Eduardo Raposo em “O Estado dentro do Estado - Autoritarismo e Instabilidade Institucional no Regime Militar - Banco Central, Petrobrás e Eletrobrás" (1991) e Luiz Aranha Correia do Lago em "A Sumoc como embrião do Banco Central e sua influência na condução da política econômica - 1945-1965" (1982).

5. Depoimento de Casimiro Ribeiro ao Cpdoc, em 1989.

6. Como chama a atenção Jairo Saddi (1997:73): “O Banco do Brasil era o agente financeiro e receptador de crédito do Tesouro Nacional, arrecadador de tributos ou rendas federais, realizador dos pagamentos e suprimentos necessários à execução do Orçamento Geral da União. Era também o executor dos serviços bancários de interesses do governo federal, inclusive de suas autarquias, e também arrecadador dos depósitos voluntários das instituições (de que tratava o inciso III do artigo 10 daquela Lei), bem como responsável pela execução dos serviços de compensação bancária".

7. De fato, o Banco Central passou a ser titular das funções das Carteiras de Câmbio e Redesconto e das Caixas de Mobilização Bancária e de Amortização do Tesouro Nacional. O Banco Central fortaleceu-se, também, por passar a controlar a emissão primária de moeda e a estimular, sob seu controle, o mercado de títulos da dívida pública (Entrevista concedida por Otávio Gouvêa de Bulhões ao Cpdoc em 1989).

8. Pedro Malan. Dicionário Histórico-Biográfico Brasileiro, p. 3.284.

9. Paulo Hortêncio Pereira Lira I (depoimento, 1989). Rio de Janeiro, Cpdoc/Banco Central do Brasil, 1990, p. 16.

10. A utilização dessa conta como artifício para driblar restrições orçamentárias mostra-se de maneira mais clara a partir da década de 1980. Segundo Saddi (1997), o saldo dessa conta evoluiu de 1,8\% do PIB brasileiro para 16\% em 1988, sendo que em alguns momentos o valor desse saldo era maior do que a base monetária em circulação.

11. Depoimento de Otávio Gouvêa de Bulhões ao Cpdoc em 1989, p. 174. 
12. Em sua fase inicial, durante o período presidencial de Castelo Branco, faziam parte do CMN nove membros: o ministro da Fazenda (seu presidente); o presidente do Banco do Brasil; o presidente do Banco Nacional de Desenvolvimento Econômico (BNDE); e mais seis membros nomeados pelo presidente da República, após aprovação do Senado Federal, por um período de seis anos, com possibilidade de recondução. Destes seis membros com mandato, quatro iriam compor a diretoria do Banco Central, enquanto os dois restantes seriam escolhidos como representantes do setor financeiro privado. Nessa arquitetura inicial, portanto, o Conselho Monetário Nacional contou com nove membros, cuja permanência deveria perdurar durante os dois primeiros anos do governo seguinte. Participavam, ainda, das reuniões do Conselho, mas sem direito a voto, os ministros da Indústria e Comércio e do Planejamento e Coordenação Econômica. As deliberações do Conselho eram tomadas considerando-se a maioria dos votos, presentes no mínimo seis membros, cabendo ao presidente do Conselho (ministro da Fazenda) o voto final (Lei 4595/64).

13. Depoimento de Casimiro Ribeiro ao Cpdoc, em 1989.

14. Depoimento de Dênio Nogueira ao Cpdoc, em 1989.

15. Entrevista concedida à revista Banco Hoje, setembro de 1989.

16. Depoimento de Casimiro Ribeiro ao Cpdoc, em 1989.

17. Depoimento de Casimiro Ribeiro ao Cpdoc, 1989.

18. “Tal formato decisório será derrogado a partir de 1974, quando, ao início do governo Geisel, nova legislação impõe sensível redução nas atribuições do CMN, restringindo igualmente o numero de seus membros. A criação do Conselho de Desenvolvimento Econômico transferiu para a instância executiva da Presidência da República o núcleo das decisões fundamentais, enfraquecendo a 'representação tecnocrática' e diminuindo as possibilidades de influência dos grupos privados" (Guimarães e Vianna, 1987:25).

19. Apesar das condições externas adversas, Geisel dá continuidade a uma política econômica com metas de crescimento elevadas. A utilização de empréstimos estrangeiros como forma de financiamento para esse crescimento fica evidente com a explosão da dívida externa nesse período.

20. Depoimento de Ernane Galvêas ao Cpdoc, 1989. Rio de Janeiro, Cpdoc/Banco Central do Brasil, 1990, p. 32.

21. Decreto 89978/85 (26 membros), Decreto 93490/86 (27 membros), Decreto-Lei 2291 / 86 ( 26 membros) e Decreto 94303/87 (27 membros). A extinção, durante o governo Sarney, do Banco Nacional de Habitação elimina um assento no CMN.

22. Depoimento prestado por Fernão Bracher a Eduardo Raposo, em 2006.

23. Depoimento prestado por Francisco Gros a Eduardo Raposo, em 2003.

24. Decretos 2.283 e 2.284 , de 1986 .

25. Depoimento prestado por Ibrahim Eris a Eduardo Raposo, em 2006.

26. Depoimento prestado por Francisco Gros a Eduardo Raposo, em 2003.

27. Depoimento prestado por Francisco Gros a Eduardo Raposo, em 2003.

28. Depoimento prestado por Francisco Gros a Eduardo Raposo, em 2003.

29. Depoimento prestado por Francisco Gros a Eduardo Raposo, em 2003.

30. Depoimento prestado por Francisco Gros a Eduardo Raposo, em 2003. 
31. Segundo Maria Clara Prado, "O presidente também indicou que gostaria de ter uma composição do Conselho Monetário Nacional (CMN) mais enxuta, diferente da proposta da equipe econômica. Queria que o conselho ficasse restrito a três membros: os ministros da Fazenda e do Planejamento e o presidente do Banco Central. Não concordou que os diretores do $\mathrm{BC}$ fizessem parte do CMN nem com as participações do presidente da CVM e do secretário do Tesouro Nacional, como pretendia a equipe do Real. Itamar achava que isso desequilibraria o colegiado em favor da autoridade monetária. [...] A implicância de Itamar, portanto, não era com a retirada dos representantes do setor privado daquele colegiado, mas com a perspectiva de as decisões do Conselho ficarem desequilibradas devido ao peso excessivo de representantes do Banco Central, como queria a equipe econômica, no que, aliás, ele tinha toda razão" (p.282).

32. Depoimento prestado por Gustavo Franco a Eduardo Raposo, em 2003.

33. Depoimento prestado por Gustavo Franco a Eduardo Raposo, em 2003.

34. O Copom foi criado pela Circular n.2698/1996 do Banco Central. É um órgão colegiado, composto pelo presidente do Banco Central e por seus diretores, cuja principal função é determinar a taxa de juros SELIC.

35. Depoimento prestado por Gustavo Franco a Eduardo Raposo, em 2003.

36. O sistema de metas de inflação foi adotado em 2000, logo apos a implementação do regime de câmbio flutuante.

37. A respeito dos argumentos que nos levaram a considerar a rotatividade dos titulares tanto do Ministério da Fazenda quando do Banco Central do Brasil como indicadores de estabilidade institucional, ver nota 1 .

38. Como já foi ressaltado, apesar da autonomia de fato desfrutada durante os dois governos Fernando Henrique, por ocasião da crise cambial de 1998, Gustavo Franco foi afastado da Presidência do Banco Central por discordar da intenção do governo em fazer flutuar a taxa de câmbio. 


\section{REFERÊNCIAS BIBLIOGRÁFICAS}

BIBOW, Jorg. (2004), “Reflections on the Current Fashion for Central Bank Independen$\mathrm{ce}^{\prime \prime}$. Cambridge Journal of Economics, vol. 28, pp. 549-576.

BLINDER, Alan S. (1999), Bancos Centrais: Teoria e Prática. São Paulo, Editora 34.

BULHÕES, Otávio Gouveia de. (1989), Entrevista concedida ao Cpdoc.

CAMPOS, Roberto. (1994), A Lanterna na Popa. Rio de Janeiro, Topbooks.

CORAZZA, Gentil. (2006), “O Banco Central do Brasil: Evolução Histórica e Institucional". Perspectiva Econômica, vol. 2, no 1, pp. 1-23.

CUKIERMAN, Alex; WEBB, Steven e NEYAPTI, Bilin. (1992), “Measuring the Independence of Central Banks and its Effect on Policy Outcomes". The World Bank Economic Review, vol. 6, no 3, pp. 353-398.

GUIMARÃES, Cesar e VIANNA, Maria Lúcia W. (1987), “Planejamento e Centralização Decisória: O Conselho Monetário Nacional e o Conselho de Desenvolvimento Econômico", in O. B. de Lima Junior e S. Abranches (orgs.), As Origens da Crise. São Paulo, Vértice.

LAGO, Luiz Aranha Correia do. (1982), A Sumoc como Embrião do Banco Central e sua Influência na Condução da Política Econômica - 1945-1965. Tese de Doutorado, Departamento de Economia, PUC-Rio, Rio de Janeiro.

LIJPHART, Arend. (2003), Modelos de Democracia. Rio de Janeiro, Civilização Brasileira.

LOHMAN, Susanne. (1998), “Federalism and Central Bank Independence: The Politics of German Monetary, 1957-92". World Politics, vol. 50, no 3.

MALAN, Pedro. (1983), Verbete Superintendência da Moeda e do Crédito (Sumoc). Dicionário Histórico-Biográfico Brasileiro. Rio de Janeiro, Fundação Getulio Vargas, p. 3284.

MAXFIELD, Sylvia. (1997), Gatekeepers of Growth: The International Political Economy of Central Banking in Developing Countries. New York, Princeton University Press.

MENDONÇA, Helder Ferreira de. (1998), “Aspectos Teóricos e Empíricos sobre Bancos Centrais Independentes: Implicações para o Caso Brasileiro". Revista de Economia Aplicada, vol. 2, no 1, pp. 83-111.

PRADO, Maria Clara. (2005), A Real História do Real. Rio de Janeiro, Record.

PATRÍCIO, Inês. (2001), Segredo, Lei e Credibilidade: A Prestação de Contas do Banco Central do Brasil. Tese (Doutorado em Ciência Política), IUPERJ, Rio de Janeiro.

QUAGLIA, Lúcia. (2005), “An Integrative Approach to the Politics of Central Bank Independence: Lessons from Britain, Germany and Italy". West European Politics, vol. 28, no 3, pp. 549-568.

RAPOSO, Eduardo. (2009), O Banco Central do Brasil: O Leviatã Ibérico - uma Interpretação do Brasil Contemporâneo, mimeo.

. (1997), O Estado dentro do Estado: Autoritarismo e Instabilidade Institucional no Regime Militar - Banco Central, Petrobras e Eletrobrás. Tese (Doutorado em Ciência Política), IUPERJ, Rio de Janeiro. 
RIGOLON, Francisco José Zagari. (1993), Independência do Banco Central: O Caso do Brasil. Dissertação (Mestrado em Economia), PUC-Rio, Rio de Janeiro.

SOLA, Lourdes; GARMAN, Christopher e MARQUES, Moisés. (2002), “Banco Central, Autoridade Política e Governabilidade", in L. Sola, E. Kugelmas e L. Whitehead (orgs.), Banco Central - Autoridade Política e Democratização: Um Equilíbrio Delicado. Rio de Janeiro, FGV Editora.

SADDI, Jairo. (1997), O Poder e o Cofre. São Paulo, Texto Novo.

SANTOS, Fabiano e PATRÍCIO, Inês. (2002), “Moeda e Poder Legislativo no Brasil: A Prestação de Contas de Bancos Centrais no Presidencialismo de Coalizão". Revista Brasileira de Ciências Sociais, vol. 17, no 49.

TAYLOR, Matthew. (2009), “Institutional Development through Policy-Making: A Case Study of the Brazilian Central Bank". World Politics vol. 61, no 3, pp. 487-515.

THELEN, Kathleen. (1999), "Historical Institutionalism in Comparative Politics". American Review of Political Science, ㄲo 2 . 


\section{ABSTRACT \\ Strong Institutions, Stable Currency, and an Autonomous Brazilian Central Bank}

The article discusses the autonomy of Brazil's Central Bank and its potential relationship to the national currency's stability. Beyond the government budget balance and the Central Bank's autonomy, we seek to demonstrate that the currency's stability also depends on the Bank's own political and institutional stability. Due to a gap in the literature, which has focused little attention on the political conditions and economic motivation by which important steps were taken towards achieving autonomy, we analyze the relations between autonomy and stability from a historical-institutional perspective. We call attention to the cyclical nature of the Brazilian economy, which alternates developmentalist policies and stabilization policies and thereby alters the Central Bank's role and degree of autonomy.

Key words: Brazil; policy; economy; Central Bank; autonomy

\section{RÉSUMÉ}

Institutions Fortes, Monnaie Stable et Autonomie de la Banque Centrale du Brésil

Dans cet article, on examine l'autonomie de la Banque Centrale du Brésil et son possible rapport à la stabilité de la monnaie nationale. On veut montrer que, au-delà de l'équilibre des comptes de l'État et de l'autonomie de la Banque Centrale, la stabilité de la monnaie dépend, aussi, de la stabilité politique et institutionnelle de la Banque elle-même. En raison de la littérature lacunaire à ce sujet - qui n'a accordé que très peu d'attention aux conditions politiques et aux motivations économiques où l'on a fait des progrès en vue de l'acquisition de l'autonomie -, on cherche ici à examiner la relation entre autonomie et stabilité, à partir d'une perspective historico-institutionnelle. Pour cela, on souligne l'aspect cyclique de l'économie brésilienne qui, dans son alternance entre politiques de développement et politiques de stabilisation, modifie, forcément, la vocation et l'autonomie de la Banque Centrale.

Mots-clés: Brésil; politique; économie; Banque Centrale; autonomie 